\title{
EFFECT OF PERFORMANCE APPRAISAL ON EMPLOYEE PRODUCTIVITY IN NIGERIAN BANKING SECTOR
}

Enekwe, Chinedu Innocent $\mathrm{Ph}_{.} \mathrm{D}^{1}$;Eziedo, KennethNnagboguPh. $\mathrm{D}^{2}$ and Agu, Charles Ilkechukwu Ph.D ${ }^{3}$

1\& 3. Department of Accountancy, Faculty of Management and Social Sciences. Caritas University Enugu. Enugu State. Nigeria.

2. Department of Business Administration, Faculty of Management and Social Sciences. Caritas University Enugu. Enugu State. Nigeria.

Corresponding author E-mail: chineduinnocent1981@gmail.com

The Study examined the effect of Performance appraisal on Employee productivity in Nigerian banking sector using Eco Bank of Nigeria Abakaliki Branch, Ebonyi State. The specific objectives were to determine the effect of performance appraisal design and method (PADM)on employee productivity (EP) in Nigerian banking sector, examine the effect of performance appraisal process (PAP) on employee productivity (EP) in Nigerian banking sector and evaluate the effect of performance-based reward (PBR) on employee productivity (EP) in Nigerian banking sector. The independent variable performance appraisal proxied by performance appraisal design and method (PADM), performance appraisal process (PAP) and performance-based reward (PBR) while dependent variable, employee productivity (EP). The descriptive research design was used for the study. The main theories that under pinned the research were the equity theory, goal-setting theory and hierarchy of needs theory. The SPSS version 20 software statistical package was used to run the Panel ordinary least square (OLS) for the study. The multiple regression model was applied in determining the extent of the effect of independent variable (performance appraisal) on dependent variable (employee productivity) of banking sector under investigation. The regression result indicated that performance appraisal design and method (PADM) and performance-based reward (PBR) have positive and insignificant effect on employee productivity while performance appraisal process (PAP) has positive and significant effect on employee productivity (EP) in banking sector. The implication of this finding is that a percentage increase of performance appraisal design and method (PADM), performance appraisal process (PAP) and performance-based reward (PBR) will lead to an increase on the employee productivity. Based on the findings, the researcher recommended among others that the organization should reduce the impression given to the employee on the design and method of measure appraisal if they are not sure of the methods. Also, performance appraisal process should however be evaluated periodically to determine how they conduct performance appraisals.

Keywords: Performance appraisal,Performance appraisal design and method, Performance appraisal process,Performance-based reward and Employee productivity.

\section{Introduction}

Performance appraisal is an evaluation done on an employee's job performance over a specific period of time. It is the equivalent of a report card on an employee and how their managers assess their performance over the prior year (Obi, 2016).Muriuki (2016), Performance Appraisal System (PAS) is amongst the great paradoxes in effective management of Human Resource (HR) in many organizations and its main purpose is to 
improve effectiveness in job performance. Performance appraisal as a system has been in existence for a few decades. Formally, evaluation of employees is believed to have been adopted in the eighteenth century and it involves assessing performance in relationship to the laid down rules, procedures and objectives of the job (Fletcher, 2004). Evaline\& Bula (2017) state that there are many outcomes that can be attained from having performance appraisal program which include continuous open communication, improved employee morale, job satisfaction, reduced employee turnover, increased employee commitment, increased motivation for both individuals and teams, feeling of equity among employees, and linkage between performance and rewards. Wanjala and Kimutai (2015) say that performance appraisal or employee appraisal is a method by which the job performance of an employee is evaluated generally in terms of quality, quantity, cost and time typically by the immediate line manager or supervisor. A performance appraisal is a part of the process of guiding and managing career development in both private and public sectors. It involves the task of obtaining, analyzing and recording information about the relative worth of an employee to the organization. Accurate appraisals are crucial for the evaluation of recruitment, selection and training procedures that lead to improved performance. Appraisals can determine training needs, occasionally and counseling needs. They can also increase employee motivation through the feedback process and may provide an evaluation of working conditions, thus improving employee productivity, by encouraging the strong areas and modifying the weak ones. Matui(2017), Performance appraisal serves as a tool for enhancing productivity in modern organizations. Through the process of performance appraisal, the productivity of organizational members is measured. It is one of the most delicate issues in human resources management because an employee's overall success in an organization depends largely on the outcome of performance appraisal. It is pertinent to state here that some bosses take advantage of this to under-estimate or under-asses the performance of employees who are not in their good book.Performance appraisal has also been looked at as the method by which the performance and productivity of each worker is measured in order to determine his or her contribution to the effort of the organization towards the achievement of the set goals and objectives. The method used in the measurement and evaluation of a worker's performance differ from one organization to another. But the ultimate purpose is to estimate the job performance of each employee towards the achievement of organizational objectives (Eldman\& Arnold, 2009).Due to this reason, management is playing an increasing important role in nearly all phase of human endeavor and is now being employed in both the public and private sector of the economy. Another factor that is very crucial to affect employee's productivity in the private sector of the economy is motivation. After the right sets of individuals have been selected to the right job, it is imperatives that they are motivated. An employee who is rightfully motivated will bring out their best in whatever capacity they are serving.

Employees are very important resource in any organization. This can be attributed to the way their performance is appraised, recognized and relevant motivation put in place (Wanjala and Kimutai, 2015). The banking sector has witnessed significant reforms from the 1990's with right sizing efforts and now the performance contracts that has become a yardstick through which employees' performance is measured.Wagacha and Maende (2017) state that the triumph of any organization mainly depends on the commitment of its human resources. To facilitate continued efficiency and effectiveness of members of staff, each organization has to carry out employee performance appraisal from time to time to keep them in check and replace, motivate, re-train or take any other appropriate action.Kuvaas (2006) explored the relationship between performance appraisal satisfaction and employee outcomes in the form of work productivity, organizational commitment and turnover retention. Mutai (2012) notes 
that a series of under-performance at commercial banks in Nigeria despite an enhanced performance appraisal system being in place forms the basis of a problem that needs investigation. Since the introduction of performance contracts in the public and private organization in Nigeria, the role and the effect of performance appraisal have remained unclear. In addition to this, performance appraisal is a requirement which goes hand in hand with performance contracting which the bank sign with employees. Without a formal study it's not possible to assess whether or not workers achieve the performance contract targets. This study therefore sought to investigate the effect of performance appraisal on employee productivity in Nigerian banking sector.

The main objective of this study is to investigate the effect of performance appraisal on employee productivity in Nigerian banking sector.

The specific objectives are:

1. To determine the effect of performance appraisal designs and methods on employee productivity in Nigerian banking sector.

2. To examine the effect of performance appraisal process on employee productivity in Nigerian banking sector.

3. To evaluate the effect of performance-based reward on employee productivity in Nigerian banking sector.

Based on the objectives of the study, the researchers formulated the following null hypotheses such as:

$\mathrm{H}_{1}$ : Performance appraisal designs and methods have no significant effect on employee productivity in Nigerian banking sector.

$\mathrm{H}_{2}$ : There is no significant effect of performance appraisal process on employee productivity in Nigerian banking sector.

$\mathrm{H}_{3}$ : Performance-based reward has no significant effect on employee productivity in Nigerian banking sector.

\section{Conceptual Framework}

\section{Performance Appraisal}

Nwema\&Gachunga (2014) defined performance appraisal system as a good instrument that can be used to improve the quality of an organization's work force performance of which it is considered as an important aspect in human resources management and as part of the control process in administration. They added that in order for an organisation to achieve its objectives, planning of the appraisal process is an important subject who should be undertaken to enable it achieves the objectives like work force development, including improvements, promotions and assignments in managerial positions, persuasion and punishment, salary increase, personnel's performance feed-back and determining their educational needs.

Natalie (2014) describes performance appraisal as a process or way of determining and communicating how the employees do their jobs and coming up with a plan for improving the process of carrying out work responsibilities. He continues that performance appraisal is essential as it gives updates on the performance of the employees; it identifies training needs and come up with plans for employee development.

Tekalegn, Solomon \&Gebre (2016) see performance Appraisal (PA) as the process of determining and communicating to employees how he or she is performing on the job and ideally establishing a plan of improvement. They add that if performance appraisal system (PAS) is successfully carried out in an organization, the employees would be able to know how well they are performing and what is expected of them in future in terms of effort and 
task direction through an established plan for performance improvement. So, performance appraisal is a useful tool for understanding and assessing employee skill and potential.

Igbojekwe\& Ugo-okoro (2015) say that performance appraisal is a systematic process that seeks to evaluate employees' performance and helps in identifying employee's potential for further growth and advancement within the organization's career ladder. They continue that the basic aim of performance appraisal system is to monitor employee performance, boost employee motivation that will in turn improve company morale and is a useful tool for understanding and assessing employee skill potential. Okafor (2005) adds performance appraisal is a process of assessing, summarizing and developing the work performance.

Obi (2016) describes performance appraisal as an evaluation done on an employee's job performance over a specific period of time. It is the equivalent of a report card on an employee and how their managers assess their performance over the year. He continues that performance appraisal has also been looked at as the method by which the performance and productivity of each worker is measured in order to determine his or her contribution to the effort of the organizational towards the achievement of the set goals and objectives.

Muriuki (2016) identifies performance appraisal as a performance measurement tool which is used to get performance information of an individual and compares them with the already set standards. He adds that performance appraisal mean those activities by which employees are assessed in an organization in order to grow their competence, raise their performance and give rewards.

Coens and Jenkins (2000) state that performance appraisal is a mandated process, in which a group of employees' work performance and personal traits over a specified period of time are individually judged, rated and described by the rater of the group and the results of the evaluation are kept by the organizations for future reference. They add that it is normally a formal process and an important part of the human resource management practices in organizations.

Ekwochi (2010) describes performance appraisal as a systematic and objective way of judging the relative wrath or ability of an employee in performing his or her task which is primary way to identify those who are performing their assigned task well and those who are not. She adds that performance appraisal is not end itself but a means to an end, that is, it seeks not to be judgment but corrective.

Malik, Mushtaq, Muhammad, Seemal\&Adeel (2014) say that Performance appraisal is one of the most significant aspects of human resource activities designed and performed in the companies as well as in every walk of life. They add that it is an act of testing, evaluating, measuring and justifying the performance displayed by the employees during a specific period of time.

Oshode, Alade\&Arogundade (2014) categorizes a four- step process of the performance appraisal system. Performance appraisal systems comprises of established performance standards, a method of determining individual performance, comparison against standards and an evaluation of performance based on the comparison. The first step of establishing performance standards outlines the employees' job responsibilities. The job standards are set against the worker performance. The second step involves pegging the worker performance (such as traits approach, behavioural approach, ranking methods, alternation ranking, and results methods, productivity measures, 360 degrees evaluation and Management by Objectives (MBO). Thirdly, there is comparison against standards. At some point, the individual work record it compared with the standards set for the job. Fourth, an evaluation of performance is made pegged on the comparison.

Performance appraisal system is an important drive that looks for better, more accurate, more cost-effective ways for of evaluating job performance and employee motivation. Performance 
appraisal system is a significant technique aimed at enhancing the performance of the employee in the organization (Oluoch, 2017).

\section{Employee Productivity}

Matui (2017) says that employee Productivity is also referred to as workforce productivity is an assessment of the efficiency of a worker or group of workers. Productivity may be evaluated in terms of output of an employee in a specific period of time.

Kibichii, Kiptum\&Chege (2016) describe employee productivity as also the evaluation of an employee's efficiency. The evaluation may be done in terms of the specific output of an employee in a specific time-period and is calculated against the average of other employees that are completing the same tasks. As the success of the organization depends on the workforce's productivity, employee productivity is paramount for enterprises. When looking at improving the employee productivity rates, organizations being to incorporate collaboration solutions into their daily workflows. To combat this issue, many organizations are today limiting the number of email processing sessions on a daily basis or limiting the accessibility of emails from the corporate network to certain hours of the day (Hanaysha, 2016).

Furthermore, Employee productivity is a metric that is calculated based on the amount of output on a project versus the amount of time it takes. It can also be measured against a standard or "base" of productivity for a group of workers doing similar work. The measurement of employee productivity will show how efficient the employees are for a task or project. This metric itself can be used to determine if a project needs more or less workers. So if the quality of work outputted is justified by the amount of hours being put in and, as a numeric measurement. There is an optimal level of productivity for each task or project where productivity is the main driver of progress (Tekalgn et al, 2016).

\section{Methods for Performance Appraisal System \\ Management by Objectives (MBO)}

The use of management objectives was first widely advocated in the 1950s by the noted management theorist Peter Drucker. Management by Objectives (MBO) methods of performance appraisal are results- oriented, that is, seek to measure employee performance by examining the extent to which predetermined work objectives have been met (Newman, Thanacoody and Hui, 2012). Usually the objectives are established jointly by the supervisor and subordinate. Once an objective is agreed, the employee is usually expected to self-audit; that is, to identify the skills needed to achieve the objective. Typically they do not rely on others to locate and specify their strengths and weaknesses. They are expected to monitor their own development and progress (Porter, 2008).

Management by objectives (MBO) is a management system designed to achieve organizational effectiveness by steering each employee's behavior toward the organization's mission. MBO is often used in place of traditional performance appraisals. The MBO process includes goal setting, planning, and evaluation. Goal setting starts at the top of the organization with the establishment of the organization's mission statement and strategic goals. The goal-setting process then cascades down through the organizational hierarchy to the level of the individual employee. An individual's goals should represent outcomes that, if achieved, would most contribute to the attainment of the organization's strategic goals. In most instances, individual goals are mutually set by employees and their supervisors, at which time they also set specific performance standards and determine how goal attainment will be measured (Nwema\&Gachunga, 2014). 


\section{Assessment Center Methods}

An assessment center refers a central location where the managers form a team to participate in job evaluation exercises invigilated by trained assessors. It is more focused on observation of behaviors across a series of select exercises or work samples (Porter, 2008). Assesses are requested to participate in in-basket exercises, work groups, computer simulations, role playing and other similar activities which require same attributes for successful performance in actual job. Well conducted assessment centre can achieve better forecasts of future performance and progress than other methods of appraisals. Also reliability, content validity and predictive ability are said to be high in Assessment Centers (Natalie, 2014). The tests also make sure that the wrong people are not hired or promoted. Finally, it clearly defines the criteria for selection and promotion. However, as the method concentrates on future performance potential it ignores past performance. It is very costly as the employees have to travel and lodge plus the use of psychologists. The rating is strongly influenced by assessors' interpersonal skills but employees with solid performers may feel suffocated in simulated situations.

\section{Degree Appraisal}

It is a technique in which performance data/feedback/rating is collected from all sections of people employee interacts in the course of his job like immediate supervisors, team members, customers, peers, subordinates and self with different weight age to each group of raters (Ohabunwa, 2009). This technique has been found to be extremely useful and effective. It is especially useful to measure inter-personal skills, customer satisfaction and team building skills. One of the biggest advantages of this system is that assesses cannot afford to neglect any constituency and has to show all- round performance. However, on the negative side, receiving feedback from multiple sources can be intimidating, threatening, and expensive and time consuming.

\section{Psychological Appraisals}

These appraisals are more directed to assess employee's potential for future performance rather than the past one. It is done in the form of in-depth interviews, psychological tests, and discussion with supervisors and review of other evaluations. It is more focused on employees emotional, intellectual, and motivational and other personal characteristics affecting his performance (Ohabunwa, 2009). This approach is slow and costly and may be useful for bright young members who may have considerable potential. However quality of these appraisals largely depends upon the skills of psychologists who perform the evaluation (Natalie, 2014).

With all these methods of ratings, the employees may be de-motivated if the appraisal process is not based on accurate and current job descriptions. But ensuring that appraisers have adequate knowledge and direct experience of the employee's performance can motivate the employees to give their best (Jayawarna, Wilson \& Macpherson, 2007). Offering adequate support and assistance to employees such as professional development opportunities can improve their motivation and performance of the staff. Failure to conduct appraisers on a regular basis due to the limitation of resources may affect the performance of the staff but regular supervisor ratings may have a positive impact on the motivation of the employees.

\section{Forms of Productivity}

Matui (2017), Productivity is an overall measure of the efficiency or ability to convert the inputs into goods or services. More specifically, productivity is the measure that shows how efficiently the required resources are utilized to achieve the objectives in terms of quantity 
and quality with reference to a point of time. Productivity is can be expressed different forms like partial factor productivity, multifactor productivity, and total productivity.

These forms are explained in the following paragraphs.

\section{Productivity Partial-Factor}

While measuring the productivity only one factor is taken into account. All factors affecting the productivity are not considered because the data are readily available pertaining to one factor. It is known as partial factor measure of productivity, in this calculation only a single input is considered in the ratio. The formula for partial-factor productivity can be the ratio of total output to a single input. This formula is being utilized by the management for their convenience as the information available relating to individual factor. Further, management can easily find out and relate to the particular activity. On the basis of this management can increase or decrease the individual factor easily to get the desired ratio of productivity. If management is interested then total of all individual factors can be taken to have multi factor productivity. Timely and prompt action can be taken by the management to meet the requirements. This partial factor productivity can be applied to capital, energy, machine, materials etc.

\section{Multifactor Productivity}

There are many input factors that affect the productivity. While calculating the productivity ratio the different input factors are considered. It takes into account the factors like labour, energy, materials and capital. These may be taken two or more at a time. Therefore, the multifactor productivity is the ratio of total output to a total of multiple factors inputs. There is no hard and fast rule that two particular factors would be considered in productivity ratio. It depends upon the requirement of the organisation and management approach. Labour and energy or labour andcapital or all the three may be taken into account. These factors give effect to the productivity so it is called multifactor productivity. The data relating to the multifactor productivity are not available readily. These are to be calculated and its bit difficult to do so. It is timing consuming also. That is why management do not prefer unless it is compulsory.

\section{Total Factor Productivity}

When productivity is measured by taking into account the effects of all factors used in production of goods or services. Total factor productivity is a broader gauge of productivity and it is calculated as follows:

Total factor productivity $=$ Total of Labour hours actually produced + Actual machine hours produced in a given time/ total of machine and labour hours available in time period.

Total output must be expressed in the same unit of measure and total input must be expressed in the same unit of measure. However, total output and total input need not be expressed in the same unit of measure. Resources are converted from one factor to the other. For example the standards can be converted to dollars and vice versa. This is done so that a single figure can be used as an aggregate measure of total input or output. For example, total output could be expressed in numbers/ meter/ kilograms/liter etc, and total input could be expressed in hours or rupees.

Total productivity ratios reflect simultaneous changes in outputs and inputs but it does not show the relation between the each factor of input and output. It does not give the separate factor wise effect that is why it is a broader approach. The management cannot take any decision for improvement in the productivity by adjusting individual input factor. It is not 
suitable for improvement in specific factor or area. The different forms of productivity are used in different countries across the world. Total Factor Productivity is a measure favored by the Japanese for measuring the national productivity. Whereas the labour factor productivity is accepted by USA. In India labour productivity and total factor productivity are being used separately for employees and national productivity

\section{Theoretical Framework}

There are many theories related to performance appraisal, the researcher believe that equity theory, expectancy theory, goal-setting theory, hierarchy of needs theory and two factor theory are appropriate for the current study.

\section{Equity Theory}

Equity simply means fairness. Workers are motivated when they discover that they are treated fairly in compensation, promotion and that there is transparency in their evaluations. Workers reduce their efforts if they feel that they are treated inequitably (Hyde, 2005).

Wagacha and Maende (2017) profound that this theory was proposed by John Stacey Adams in 1963. The theory suggests that the higher an individual's perception of equity, the more motivated they will be and vice versa. The theory shows that inequities, perceived or real, can harm an employee's motivation. Employees who feel they are being treated inequitably will be emotionally motivated to gain equity. This may be through decreased input or push for more pay. Furthermore, employees may be unwilling to do any extra work and only do their jobs and little else. These outcomes can harm an organizations bottom line. Equity theory therefore shows that employees' perceptions do matter. Adams theory calls for a fair balance to be struck between an employee's input and output. Input may refer to hard work, skill level, acceptance and enthusiasm while outputs may refer to salary, benefits and recognition. One of the independent variables in this study is employee perception and the role it plays on employee productivity. This variable will derive from the equity theory.

\section{Expectancy Theory}

Expectancy theory was propounded by Vroom in 1964 which indicates that employees will be motivated to exert high level of effort when they believe that their efforts will lead to higher performance (expectancy), higher performance will lead to rewards (instrumentality) and rewards are valuable to them (valence). This effort will lead to good performance appraisal and followed by organization rewards such as bonus, salary increment or promotion which later satisfy personal goals. This theory is based on the hypothesis that individuals adjust their behavior in the organization on the basis of anticipated satisfaction of valued goals set by them. The individuals modify their behavior in such a way which is most likely to lead them to attain these goals. This theory underlies the concept of performance management as it is believed that performance is influenced by the expectations concerning future events (Wagacha\&Maende, 2017).

Muriuki (2016) says that the theory is also referred to as expectancy valence theory. Expectancy Theory was brought forth by Vroom (1964) and its idea is that people's expectations in their performance affect their behaviour and the reward they seek. It argues that motivation comes about through expected performance outcome and the attached level of value to the outcome by the individual. According to Vroom organizational behaviour assessment is important. He argues that motivation of people depends on their expectations in terms of probability that effort leads to performance, instrumentality or assumed connection between performance and rewards, and valence which is the assumed value attached to the reward. He added that if people accept as true a certain worth of a goal and that they will achieve it through their actions; they will be motivated to achieve it. Vroom's theory asserts 
that people's motivation towards doing anything is as a result of the individual putting a certain value on the goal and the probability of achieving that goal. The theory also helps managers to understand the relationship between motivation, performance and pay. Vroom points out that motivation depends on the anticipation that effort will bring about performance.

\section{Goal-Setting Theory}

Goal-setting theory had been propounded by Edwin Locke in the year 1968. This theory suggests that the individual goals established by an employee play an important role in motivating him/her for superior performance. This is because the employees keep following their goals. If these goals are not achieved, they either improve their performance or modify the goals and make them more realistic (Tekalegn et al, 2016). The theory emphasizes the important relationship between goals and performance. Research supports predictions that the most effective performance seems to result when goals are specific and challenging, when they are used to evaluate performance and linked to feedback on results, and create commitment and acceptance. The motivational impact of goals may be affected by moderators such as ability and self-efficacy. Managers widely accept goal setting as a means to improve and sustain performance.

Muriuki (2016), the theory was advanced by Lotham and Locke in 1979, when they argued that goals set for employees can motivate them and thus improve their performance. Employees link target to organization goals where they assess themselves and change their behaviour to attain those targets. When goals are specific, performance and motivation go up. This also happens when challenging but achievable goals are set and feedback is given on their performance. They also point out that employees should also participate in goal setting so as to own them. Feedback is also important as it motivates the employees to achieve high goals. Newstrom (2011) believes that setting of goals motivates because there is a deficit to be met between the current and future performance. This creates tension and the employee reduces it by attaining the goals. This in turn raises employees drive, gives competence in work and raises self esteem which further stimulates the need for personal development. Luthans (2011) points out those goals give direction to the behaviour of employees and gear their efforts to particular outcomes.

\section{Hierarchy of Needs Theory}

Wagacha and Maende (2017) indicate that this is a theory proposed by Abraham Maslow in 1954 and is usually portrayed in the shape of a pyramid with the most fundamental needs at the bottom. It is a motivational theory in psychology comprising a five tier model of human needs often depicted as hierarchical levels within a pyramid. Maslow asserted that people are motivated to achieve certain needs and that some needs take precedence over others. Our most basic needs, according to the theory, is physical survival. Maslow avows that individuals must satisfy lower level needs before progressing to meet higher level growth needs. The theory suggests that before the organizations needs are met, the basic needs of the employee's must be met. A tired and hungry employee must first fulfill their basic physiological needs first. Employees need to feel emotionally and physically safe and accepted within the organization to progress and reach their full potential. One of the independent variables in this study is performance based pay and the role it plays on employee productivity. This variable will be anchored on Maslow's hierarchy of needs theory. 
Two Factor Theory

Wagacha and Maende (2017) say that two factor theory is also known as the hygiene theory, it states that there are certain factors in the work place that cause job satisfaction while a separate set of factors cause dissatisfaction. This theory was developed by Fredrick Herzberg who theorized that job satisfaction and job dissatisfaction act independently of each other. According to the theory, individuals are not content with the satisfaction of lower-order needs like salary and pleasant working conditions. Rather, individuals look for the gratification of higher level psychological needs having to do with achievement, recognition, responsibility, advancement and the nature of the work itself.

Muriuki (2016) suggested that man lives at two levels; the physical and psychological levels. His study was based on good and bad experiences of work of 200 engineers and accountants to test man's two needs, his need as an animal and avoid pain and his need as a human to grow psychologically. The respondents were urged to recall good and negative experiences during working time. Herzberg came up with two factor theory. Several factors such as achievement, recognition, work itself, responsibility, advancement and growth led persistently to employees satisfaction while other factors led to dissatisfaction such as company policy, supervision, work condition, salary, status, security among others. The theory suggests that to improve job attitudes and productivity, administrators must recognize and attend to the two sets of characteristics and not assume that increase in satisfaction leads to decrease in dissatisfaction. The dependent variable in this study is employee productivity. This variable will derive from the two factor theory.

The researcher anchored this study on these three theories that is equity theory and goalsetting theory and hierarchy of needs theory because he believes that they are more appropriate for this study.

\section{Empirical Review}

Many empirical studies have revealed that an effective performance appraisal as part of the human resource management makes a difference to achieve goals of the organization.

Muriuki (2016) studied the effect of performance appraisal on employee motivation at the Ministry of East Africa Community, Labour and Social Protection. The research study adopted a descriptive research design in form of a survey and a sample size of one hundred and twenty (120) respondents drawn from all the departments in the Ministry ranging from different job groups which included the senior management (Job Group P and Above), middle level management (job group $\mathrm{J}$ to $\mathrm{N}$ ) and lower level employees (job group A to $\mathrm{H}$ ). Stratified random sampling was used as all the respondents were drawn from different levels or strata within the Ministry. Structured questionnaires developed in form of a five point likert scale was used for data collection as they were easy to administer and cheap in terms of cost and time. Data was collected and analyzed by use of scientific package for social sciences (SPSS). A regression model was used to determine the co-efficient of the effect of performance appraisal on employee motivation. The study shows that there is a strong positive significant correlation between performance appraisal and employee motivation and it indicates that performance appraisal system has a significant impact on employee motivation at the Ministry of Labour, East Africa Community and Social Protection.

Hanayaha (2016) investigated the improving employee productivity through work engagement using empirical evidence from higher education sector. This study examines the effect of work engagement on employee productivity in higher education sector. The primary data using survey instrument were collected from a sample of 242 employees at public universities in northern Malaysia using an online survey method. The collected data was analyzed using SPSS and Structural equation modelling on AMOS. The results revealed that 
work engagement (vigor, dedication, and absorption) had significant positive effect on employee productivity.

In the study of Mwema and Gachunga (2014) on the influence of performance appraisal on employee productivity in organization using a case study of selected WHO offices in East Africa. The descriptive design was adopted in this study. The study population was the 410 employees while the sample size was 105 employees of the World Health Organization of Kenya and Sudan Country Offices and Garissa sub-offices. The Stratified sampling was used to select the sample of the study. The primary (questionnaires) and secondary data were used for the study. The data collected was analyzed using the Statistical Package for Social Sciences (SPSS). The data was sorted and coded into the SPSS and analyzed using descriptive statistics. The study indicates that there is a positive relationship between performance appraisal systems and employee productivity.

Natalie (2014) examinedthe effect of performance appraisal on employee motivation using a survey of slum based Non-Governmental Organizations in Nairobi. The study adopted a descriptive research design. The population of interest consists of all 300 employees of slum based NGOs and sample size of 171 was selected using stratified sampling method. Data was collection using structured questionnaires. The data was analyzed using the Statistical Package for Social Sciences (SPSS) into frequency distribution, percentages and Pearson correlations. The data was presented using tables and charts. The results indicate that performance has a positive effect on employee motivation of Non-Governmental Organizations in Nairobi.

Tekalegn, et al (2016) explored the effect of Performance appraisal on employee performance using a survey on administrative staff of Hawassa University. The descriptive research design was employed. The population of the study was 2821 staff while the simple size was 338 staff. The primary source of data was adopted for the study. The data were collected through structured questionnaires from 320 permanent administrative staff. The simple random sampling technique was used for the study. The researcher employed both Pearson correlation and multiple regression analysis using Statistical packages for social sciences (SPSS) to run the analysis. The findings reveal that there is positive and significant relationship between performance appraisal and employee performance. The results also indicate that performance appraisal has significant effect on employee performance of administrative staff of Hawassa University.

Igbal, Ahmad, Haider, Batool and Qurat-ul-ain (2013) determined the impact of performance appraisal on employee's performance involving the moderating role of motivation. The researcher adopted sampling techniques for the study. The study sample size was 150 numbers of employees using simple random sampling among the banks of Dera Ghazi Khan. The primary data were collect through standard questionnaire. The method of data analysis was correlation coefficient through IBM SPSS and Amos Software. The results indicate that there is positive relationship between performance appraisal and employee's performance. Also, motivation as a moderator has strong positively affected the relationship between performance appraisal and employee's performance.

\section{Methodology}

The research design adopted by this study was the descriptive research design method.The study was carried out in Nigeria, with particular reference to Eco bank of Nigeria Abakaliki Branch Ebonyi State.The data for the study was basically from primary source (questionnaires) collected from Eco bank of Nigeria Abakaliki Branch Ebonyi State. The researcher also used the gathered data from the Eco bank of Nigeria Abakaliki Branch Ebonyi State to determine all the variables (both independent and dependent). The stratified random sampling technique was used to select the sample of the study.The respondents were expected 
to provide answers to the open ended questions. In the case of closed ended questions provide a greater uniformity of responses and were easily. The questionnaire was split into five sections. The first section asked questions concerning the general responded information. The second section asked questions concerning employee productivity. The third section, determine the effect of the performance appraisal design and methods on employee productivity. The fourth section, examine the effect of the performance appraisal process on employee productivity. The fifth section, evaluate the effect of the performance-based reward on employee productivity. A five-point Likert-type scale and rankings was used (ranging strongly disagree, disagree, strongly agree, agree and neutral) to reflect the appropriate levels of measurement necessary for statistical analysis. The econometric method adopted for this study was Ordinary Least Square (OLS) method of estimation. The collected data were coded and entered into the Statistical Package for Social Sciences (SPSS) program according to each variable of the study for analysis.

\section{Model Specification}

In carrying out this research work on the effect of performance appraisal on employee productivity, we developed a compact form of our as follows:

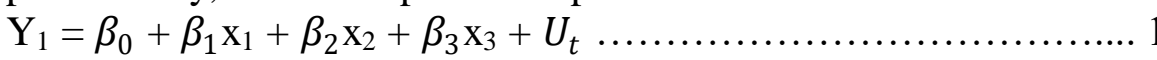

Where:

$\mathrm{Y}_{1}=$ Dependent variable of organisation

$\mathrm{X}=$ Independent variable of organisation

$\beta_{0}=$ Intercept for $\mathrm{X}$ variable of $\mathrm{i}$ organisation

$\beta_{1}-\beta_{2}=$ Coefficient for the independent variables $\mathrm{X}$ of organisation, denoting the nature of the relationship with dependent variable $\mathrm{Y}$ (parameters)

$\mathrm{U}_{\mathrm{t}}=$ Error term

Model:

$E P_{i}=f\left(P A D M_{i}, P A P_{i}, P B R_{i}\right)$

$E P_{i}=\beta_{0}+\beta_{1} P A D M_{i}+\beta_{2} P A P_{i}+\beta_{2} P B R_{i}+U_{t}$

Where:

$\mathrm{EP}=$ The employee productivity was measured by five structured questions in section $\mathrm{B}$ of the questionnaires.

PADM $=$ The performance appraisal design and methods was measured by five structured questions in section $\mathrm{C}$ of the questionnaires.

$\mathrm{PAP}=$ The performance appraisal process was measured by five structured questions in section $\mathrm{D}$ of the questionnaires.

$\mathrm{PBR}=$ The performance-based reward was measured by five structured questions in section $\mathrm{E}$ of the questionnaires.

$\sigma_{0}, \alpha_{0}, \mu_{0}, \beta_{0}$ and $\rho_{0} .=$ Intercept or conctant term.

$\beta_{1} \beta_{2, \text {. }}=$ Slope or Coefficient of the independent variables.

$U_{t}=$ Stochastic term or error term. 


\section{Results}

Table1: Descriptive Statistics

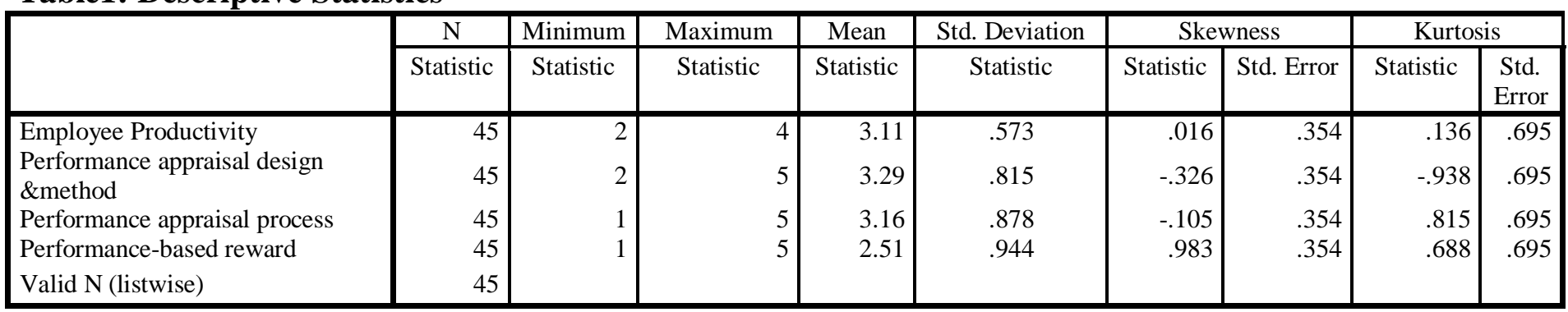

Source: Authors' SPSS Version 20 output

The descriptive Statistics table above shows that Performance appraisal design \& method (PADM) has the highest mean value while Performance-based reward (PBR) has the lowest value of mean. Also, the low standard deviation of Performance-based reward (PBR) implies that it does not deviate so much from the mean while the standard deviation of Performance appraisal design \& method (PADM) substitution are relatively high implying much deviation from their respective means which is also reflected in the squared deviation figures. The table further indicates that the observed distribution for Performance appraisal design \& method (PADM), Performance appraisal process (PAP) and Performance-based reward (PBR) have skewness statistic which estimate the asymmetry of the distribution of time series data around its mean of $-0.326,-0.105$ and 0.983 respectively. The kurtosis statistic, which measures how peak or flat the distribution of series for Performance appraisal design \& method (PADM), Performance appraisal process (PAP) and Performance-based reward (PBR) were -0.938, 0.815 and 0.688 respectively. The implication of the result was that the observed distribution of for Performance appraisal design \& method (PADM), Performance appraisal process (PAP) and Performance-based reward (PBR) were abnormally distributed.

Table 2: Regression Analysis

Dependent variable: Employee Productivity (EP)

Method: Panel least squares

Total panel observations: 45

\begin{tabular}{|c|c|c|c|c|}
\hline Variables & Coefficient & Std. Error & t-statistic & Prob. \\
\hline Constant & 1.385 & 0.188 & 7.375 & 0.000 \\
\hline Performance appraisal design \& method (PADM) & 0.004 & 0.088 & 0.045 & 0.965 \\
\hline Performance appraisal process (PAP) & 0.415 & 0.107 & 3.897 & 0.000 \\
\hline Performance-based reward (PBR) & 0.160 & 0.091 & 1.763 & 0.085 \\
\hline $\mathrm{R}^{2}$ & 0.773 & & & \\
\hline Adj. $R^{2}$ & 0.756 & & & \\
\hline F-statistic & 46.426 & & & \\
\hline Prob(F-statistic) & 0.000 & & & \\
\hline Durbin-watson stat & 0.850 & & & \\
\hline
\end{tabular}

Source: Authors' SPSS version 20 Output

The regression analysis above shows that R-Squared is $77.3 \%$ of the variations in Employee Productivity (EP) of Eco bank of Nigeria were caused by the level of Performance appraisal design \& method (PADM), Performance appraisal process (PAP) and Performance-based reward (PBR) While 22.7\% of the variation in Employee Productivity (EP) were caused by other factors outside our model. The adjusted R-Squared which indicates a figure greater than $50 \%$ implies that Performance appraisal design \& method (PADM), Performance appraisal process (PAP) and Performance-based reward (PBR) were the major determining factors of 
Employee Productivity (EP) of Eco bank of Nigeria. The Durbin-Watson Statistic is 0.850 while F-Statistic is 46.426 at $\mathrm{P}$-value of 0.000 .

\section{Decision Rule}

To accept or reject a hypothesis emphasis is on the significance of the t-stat. there are two basic approaches to determining whether the result is significant or not: compare the calculated t-stat with the tabulated t-stat and if the calculated t-stat is greater than the tabulated t-stat we accept the alternative hypothesis and reject the null hypothesis and conclude that the result is significant but if the calculated t-stat is less than the tabulated t-stat then we reject the alternative hypothesis and accept the null hypothesis and conclude that the result is insignificant. Secondly the result of the prob of t-stat is compared with 0.05 and if the result is less than 0.05 we accept the alternative hypothesis and reject the null hypothesis and conclude that the result is statistically significant but if it is greater than 0.05 we reject the alternative hypothesis and accept the null hypothesis and conclude that it is insignificant. The result of Panel least squares model shown above indicates that the coefficient of Performance appraisal design and methods (PADM) is 0.004 while the $t$-stat is 0.045 which is less than critical value of 2.0000 and P-value of t-stat is 0.965 greater than 0.05 . This implies that Performance appraisal design and methods (PADM) has a positive and insignificant effect on Employee Productivity (EP) in Nigerian banking sector under consideration. This however shows that a percentage increase in the PADM will lead to about $4.5 \%$ increase in the Eco bank in Nigeria Employee productivity. So, the researcher rejects alternative hypothesis $\left(\mathrm{H}_{\mathrm{i}}\right)$ and accepts the null hypothesis $\left(\mathrm{H}_{0}\right)$ of hypothesis one which states that Performance appraisal design and methods (PADM) has no significant effect on Employee Productivity (EP) in Nigerian banking sector.

Also, the result shown that the coefficient of Performance appraisal process (PAP) is 0.415 while the t-stat is 3.897 which is greater than critical value of 2.0000 and P-value of $t$-stat is 0.000 less than 0.05. This implies that Performance appraisal process (PAP) has a positive and significant effect on Employee Productivity (EP) of the banking sector under consideration. This however shows that a percentage increase in the PAP will lead to about $41.5 \%$ increase in the Eco bank in Nigeria Employee productivity. So, the researcher rejects null hypothesis $\left(\mathrm{H}_{0}\right)$ and accepts the alternative hypothesis $\left(\mathrm{H}_{\mathrm{i}}\right)$ of hypothesis two which states that there is a significant effect of performance appraisal process (PAP) on Employee Productivity (EP) in Nigerian banking sector.

Finally, the result of Panel least squares model shown above indicates that the coefficient of Performance-based reward (PBR) is 0.160 while the t-stat is 1.763 which is less than critical value of 2.0000 and $\mathrm{P}$-value of $\mathrm{t}$-stat is 0.085 greater than 0.05 . This implies that Performance-based reward (PBR) has a positive and insignificant effect on Employee Productivity (EP) of the banking sector under consideration. This however shows that a percentage increase in the PBR will lead to about $16 \%$ increase in the Eco bank in Nigeria Employee productivity. So, the researcher rejects alternative hypothesis $\left(\mathrm{H}_{\mathrm{i}}\right)$ and accepts the null hypothesis $\left(\mathrm{H}_{0}\right)$ of hypothesis three which states that Performance-based reward (PBR) has no significant effect on Employee Productivity (EP) in Nigerian banking sector.

So, the test output described to the results and the emerging multiple regression equation in the table above is as:

$(\mathrm{EP})_{\mathrm{y}}=0.188+0.088(\mathrm{PADM})_{\mathrm{y}}+0.107(\mathrm{PAP})_{\mathrm{y}}+0.091(\mathrm{PBR})_{\mathrm{y}}+\sum \mathrm{i}$

\section{Summary of Findings}

1. Performance appraisal design and methods (PADM) has a positive and insignificant effect on Employee Productivity (EP) inNigerian banking sector. The implication is 
that a percentage increase in the PADM will lead to an increase in the Eco bank in Nigeria Employee productivity.

2. There is a positive and significant effect of Performance appraisal process (PAP) on Employee Productivity (EP) in Nigerian banking sector. This implied that a percentage increase in the PAP will lead to an increase in the Eco bank in Nigeria Employee productivity.

3. Performance-based reward (PBR) has a positive and insignificant effect on Employee Productivity (EP) in Nigerian banking sector. The implication is that a percentage increase in the PBR will lead to an increase in the Eco bank in Nigeria Employee productivity.

\section{Recommendations}

Based on the findings, the researcher recommended among others that:

1. The organization should reduce the impression given to the employee on the design and method of measure appraisal if they are not sure of the methods.

2. The performance appraisal process should however be evaluated periodically to determine how they conduct performance appraisals.

3. The management should always communicate to the employees the reward for high productivity and importance of performance appraisal so as to accept it and see it as a means of improving their performance rather that punishing them.

\section{References}

1. Coens, T \& Jenkins, M (2000). Abolishing Performance Appraisals. San Francisco: CA Berrett-koehler publishers.

2. Ekwochi, E.A (2010). The effect of Performance Appraisal in an Organization. Review of Public Administration \& Management, 1(2), 214 - 226.

3. Eldman, D.C \& Arnold, H (2009). Managing individual and Group Behaviour in Organism. Japan: McGraw Hill Book Company.

4. Evaline, H \& Bula, H (2017). Performance Appraisal System and Employees Performance in Commercial Banks in Nairobi City County, Kenya. International Journal of Current Aspects in Human Resource Management (IJCAHRM), 1(1), 114 - 125.

5. Fletcher, C (2004). Appraisal and Feedback: Making Performance Review Work (3 ${ }^{\text {rd }}$ ed.). London: Palmgrave Publishers.

6. Hanaysha, J (2016). Improving Employee Productivity through work engagement: Evidence from Higher Education Sector. Management Science Letters, 6, 61 - 70.

7. Hyde, A.C (2005). The New Environment for Compensation and Performance Evaluation in the Public Sector, Public Personnel Management. London: Palmgrave Publishers.

8. Igbal, N; Ahmad, N; Haider, Z; Batool, Y \&Qurat-ul-ain (2010). Impact of Performance Appraisal on Employee's Performance involving the Moderating Role of Motivation. Arabian Journal of Business and Management Review (OMAW Chapter), 3(1), 37 - 56.

9. Igbojekwe, P.A \& Ugo-okoro, C.P (2015). Performance Evaluation of Academic Staff in Universities and Colleges in Nigeria: The Missing Criteria. International Journal of Education and Research, 3(3), $627-640$.

10. Jayawarna, D; Wilson, A \& Macpherson, A (2007). Training Commitment and Performance in Manufacturing SMEs. Journal of Small Business and Enterprises Development, 14(2), $321-338$.

11. Kibichii, K.E; Kiptum, K.G \&Chege, K (2016). Effects of Performance Management Process on Employee Productivity: A Survey of Commercial Banks in Turkana County. IOSR Journal of Business and Management (IOSR - JBM), 18(11), 52 - 64. 
12. Kuvaas, B(2006). Performance Appraisal Satisfaction and Employee Outcomes: Mediating and Moderating roles of Work Motivation. International Journal of Human Resource Management, 17(3), 504 - 522.

13. Luthans, F (2011). Reinforce for Performance: the need to go beyond pay and even reward. Academy of Management Executive, 13, 49 - 57.

14. Malik, S; Mushtaq, A.B; Muhammad, A.T; Seemal, M \&Adeel, M (2014). Impact of Performance Appraisal on Employee Performance. International Journal of Resources Development and Management, 3(1), 22 - 24.

15. Matui, J.K (2017). Employee Productivity on Organisational Performance in the Kenyan Banking Sector. A Case of Kenya Commercial Bank. MBA Project, School of Business, Kenyatta University.

16. Muriuki, C.W (2016). Effect of Performance Appraisal on Employee Motivation at Ministry of East African Community, Labour and Social Protection. MBA Project, School of Business, University of Nairobi.

17. Natalie, C.C (2014). The Effect of Performance Appraisal on Employee Motivation: A Survey of Slum Based Non-Governmental Organisations in Nairobi. M.Sc Project, Chandaria School of Business, United States International University-Africa.

18. Nwema, N.W \&Gachunga, H.G (2014). The Influence of Performance Appraisal on Employee Productivity in Organisations: A Case Study of Selected WHO Offices in East Africa. International Journal of Social Sciences and Entrepreneurship, 1(11), 324 - 337.

19. Newman, A; Thanacoody, R \& Hui, W (2012). The Impact of Employee Perceptions of Training on Organisational Commitment and Turnover: A Study of Multinationals in the Chinese Service Sector. Ph.D Thesis, Nottingham University Business School, Ningbo China.

20. Obi, J.N (2016). Performance Appraisal as a tool for enhancing Productivity in an Organisation. International Journal of Innovations in Sustainable Development, 7(2), 1 35.

21. Ohabunwa, S (2009). Nigeria Business Environment in the New Millennium. A Paper Presented for HRDB UNILAG on Renovating our Corporate Management Practices for the New Millennium, Wednesday $19^{\text {th }}$ May.

22. Okafor, T (2005). Performance Appraisal a chore or a cure: A Review of Public Sector Approach of Nigerian Universities. Conference on Trend in the Management of Human Resources in Higher Education, 25-26 August at the OECD Headquarter, Paris.

23. Oluoch, P (2017). A Survey of the Relationship between Performance Appraisal Practices, Motivation and Job Satisfaction on Employees of Commercial Banks in Nairobi. MBA Project, School of Business, University of Nairobi.

24. Oshode, A.A; Alade, O.S \&Arogundade, K.K (2014). Performance Appraisal in the Nigerian Banking Sector: The individual and joint variables analyses. European Journal of Business and Management, 6(5), 140 - 147.

25. Omusebe, J.M.S; Gabrieb, K \& Douglas, M (2013). Effects of Performance Appraisal on Employee Productivity: A Case Study of Mumias Sugar Company Limited. International Journal of Innovative Research and Development, 2(9), 51 - 57.

26. Porter, H (2008). The Measurement of Organizational Commitment. Journal of Vocational Behaviour, 14, 224 - 247.

27. Wagacha, K.N \&Maende, C (2017). Performance Appraisal System and Employee Productivity in Commercial Banks in Nairobi County, Kenya. International Academic Journal of Human Resource and Business Administration, 2(4), 329 - 346.

28.Wanjala, M.W \&Kimutai, G (2015). Influence of Performance Appraisal on Employee Performance in Commercial Banks in Trans Nzoia County Kenya. International Journal of Academic Research in Business and Social Sciences, 5(8), 332 - 343. 